\title{
Hubungan antara Dukungan Keluarga dengan Kejadian Depresi pada Penderita Penyakit Ginjal Kronik yang Menjalani Terapi Hemodialisa di RSUD dr. Dradjat Prawiranegara Serang
}

\author{
Lukmanulhakim $^{1}$, Lismawati $^{2}$ \\ ${ }^{1}$ Program Studi Profesi Ners STIKes Faletehan Serang \\ ${ }^{2}$ Program Studi Ilmu Keperawatan STIKes Faletehan Serang \\ Jl. Raya Cilegon, KM.06 Pelamunan Kramatwatu Serang - Banten \\ Email : lukmanulhakimshodrudin@yahoo.com
}

\begin{abstract}
Abstrak
Penyakit Ginjal Kronik (PGK) terjadi perlahan-lahan, bisa dalam hitungan bulan bahkan tahun dan sifatnya tidak dapat disembuhkan. Hemodialisa merupakan suatu metode terapi dialisis yang digunakan untuk mengeluarkan cairan dan produk limbah dari dalam tubuh ketika secara akurat atau progresif. Depresi merupakan salah satu bentuk gangguan emosi bagi penderita ginjal kronik yang ditandai perasaan tertekan, sedih, tidak berharga, tidak berarti, tidak memiliki semangat dan pesimis tentang masa depan. Pencegahan depresi dapat dilakukan dengan diterapkannya sistem dukungan keluarga yang terdiri dari dukungan informasi, penghargaan, instrumental, dan emosional. Penelitian ini bertujuan untuk mengetahui hubungan antara dukungan keluarga dengan kejadian depresi pada penderita Penyakit Ginjal Kronik yang menjalani terapi hemodialisa di RSUD dr. Dradjat Prawiranegara tahun 2016. Desain penelitian menggunakan studi Cross Sectional. Sampel dalam penelitian ini sebanyak 60 responden yang meliputi pasien dan keluarga dengan tehnik pengambilan sampling menggunakan tehnik purposive sampling. Instrumen yang digunakan untuk mengukur tingkat depresi menggunakan Back Depression Inventory (BDI) dan Intrumen Dukungan keluarga yang diadopsi dari Friedman untuk mengukur dukungan keluarga. Analisa data bivariat menggunakan Uji Chi-square. Hasil penelitian diperoleh bahwa hampir sebagian besar responden yang memiliki dukungan keluarga positif (47\%), sebagian besar responden memiliki kejadian depresi minimal (64\%). Hasil analisis bivariat menunjukkan ada hubungan yang signifikan antara dukungan keluarga $(p=0,010)$ dengan kejadian depresi. Dukungan keluarga sangat dibutuhkan dalam proses penyembuhan/ pemulihan penderita penyakit ginjal kronik yang menjalanu terapi hemodialisa. Orang yang hidup dalam lingkungan yang supportif dengan adanya perhatian, kasih sayang, motivasi kondisinya akan jauh lebih baik daripada mereka yang tidak memilikinya. Penelitian ini diharapkan dapat dijadikan sumber informasi dalam memberikan intervensi pencegahan depresi kepada penderita penyakit ginjal kronik terapi hemodialisa.
\end{abstract}

\section{Kata Kunci : Depresi, Dukungan Keluarga, Penyakit Ginjal kronik.}

Rujukan artikel penelitian:

Lukmanulhakim, Lismawati. Hubungan antara dukungan keluarga dengan kejadian depresi pada penderita penyakit ginjal kronik yang menjalani terapi hemodialisa di RSUD dr. Dradjat Prawiranegara Serang. Jurnal Ilmiah Keperawatan Indonesia.. 2017; 1 (1): 1-12. 


\begin{abstract}
Chronic Kidney Disease (CKD) occurred slowly, could be in a matter of months or even years and is not be healed. Hemodialysis is a method of dialysis used to remove fluid and waste products from the body when accurately or progressive. Depression is a form of emotional disorder for patients with chronic kidney that show depressed feelings, sad, worthless, meaningless, don't have morale and pessimistic about the future. To prevent depression can be done with the implementation of the family support system consisting of information support, appreciation, instrumental and emotional. The purpose of this researche is to know the relation of family support with the incidence of depression of Chronic Renal Disease who underwent hemodialysis therapy in dr Dradjat Prawiranegara Hospital Serang 2016. The design of the research was cross sectional. The samples in this research are 60 respondents with purposive sampling tehnique. The instrument used to measure the level of depression using the Beck Depression Inventory (BDI) and the Instrument for family Support, adopted by Friedman to measure family support. The bivariate analysis by Chi-square test. The research is in the hemodialysis hospital dr Dradjat Prawiranegara in November 2016. Primary data from observations and measurements using questionnaires and measuring tools. The research results showed that almost of respondents have fair family support (46,7\%), most of respondents have minimal depression (64,3\%). Univariate results showed that there are a significant relationship between family support $(p=0,010)$ with the incidence of depression. Family support is needed in the process of healing / recovery of patients with chronic kidney disease who underwent hemodialysis therapy. People who live in an environment which is supportive to their attention, affection, motivation will be much better condition than those who do not have it. This research is expected to be a source of further information and study materials to provide nursing intervention especially to patients with Chronic Kidney Disease with therapy of Hemodialysis.
\end{abstract}

Keywords $\quad$ : Family Support, Depression, Cronic Renal Disease 


\section{PENDAHULUAN}

Penyakit Ginjal Kronik (PGK) atau penyakit ginjal tahap akhir merupakan salah satu penyakit yang menjadi masalah besar di dunia. Angka kejadian penyakit ginjal kronik di Indonesia dengan hemodialisis semakin meningkat setiap tahunnya. Berdasarkan data Indonesian Renal Registry (IRR) bahwa pada tahun 2013 penderita penyakit ginjal kronik baru sebanyak 15.128 dan pada tahun 2014 meningkat menjadi 17.193 orang. Diagnosa pasien hemodialisis terbanyak (84\%) adalah penyakit ginjal tahap akhir/ ESRD (Report of Indonesian Renal Registry, 2014).

Tingginya prevalensi penyakit ginjal kronis juga terjadi di Indonesia, karena angka ini dari tahun ke tahun terus mengalami kenaikan. Jumlah penderita penyakit ginjal kronis di Indonesia pada tahun 2011 tercatat 22.304 dengan 68,8\% kasus baru dan pada tahun 2012 meningkat menjadi 28.782 dengan 68,1\% kasus baru (Perhimpunan Nefrologi Indonesia, 2012). Data Riset Kesehatan Dasar (Riskesdas) tahun 2013, penyakit ginjal kronis masuk dalam daftar 10 penyakit tidak menular (Riskesdas Prov. Banten, 2013).

Prevalensi gagal ginjal di Indonesia sekitar 0,2\%. Prevalensi pada kelompok umur 35-44 tahun (0,3\%), diikuti umur 45-54 tahun $(0,4 \%)$, dan umur 55-74 tahun $(0,5 \%)$ dan tertinggi pada kelompok umur $\geq 75$ tahun $(0,6 \%)$. Prevalensi gagal ginjal kronis tertinggi di tiga provinsi yaitu provinsi Sulawesi Tengah yaitu $0,5 \%$ kemudian provinsi Aceh, Sulawesi Utara, Gorontalo yaitu 0,4\% dan kemudian provinsi Jawa Tengah, Jawa Barat, DIY, Jawa Timur $(0,3 \%)$ dan Banten yaitu sebesar 0,2\% (Riskesdas, 2013).

Penyakit Ginjal Kronik (PGK) terjadi perlahan-lahan, bisa dalam hitungan bulan bahkan tahun dan sifatnya tidak dapat disembuhkan. Perburukan fungsi ginjal terjadi apabila pasien tidak melakukan pengobatan secara teratur. Selama ini dikenal dua metode dalam penanganan gagal ginjal. Pertama dengan cara transplantasi ginjal dan kedua dengan cara hemodialisa. Hemodialisa adalah suatu metode terapi dialisis yang digunakan untuk mengeluarkan cairan dan produk limbah dari dalam tubuh ketika secara akurat atau progresif ginjal tidak mampu melaksanakan proses tersebut (Arif \& Kumala, 2011). Pasien harus mengalami 
dialisis sepanjang hidupnya atau sampai mendapat ginjal baru melalui operasi pencangkokan (Smeltzer, Bare, Hinkle, \& Cheever, 2010).

Hemodialisis merupakan terapi yang paling sering digunakan pada penderita gagal ginjal kronis. Terapi hemodialisis sering disebut juga sebagai terapi pengganti ginjal karena berfungsi untuk mengeluarkan sisa-sisa metabolisme atau racun tertentu dari peredaran darah manusia, seperti urea, kreatinin, asam urat, dan zat-zat lain melalui membran semi permeabel sebagai pemisah darah dan cairan dialisat pada ginjal buatan dimana terjadi proses difusi, osmosis, dan ultra filtrasi (Arif \& Kumala, 2011).

Salah satu masalah psikologis yang penting pada penderita ginjal kronik yang menjalani terapi hemodialisa adalah depresi karena dapat mempengaruhi pengeluaran, meningkatkan resiko hospitalisasi, bunuh diri, kematian, kepatuhan dialisis, pengobatan, status nutrisi, ketahanan tubuh dan insiden peritonitis (Smeltzer, Bare, Hinkle, \& Cheever, 2010). Hal ini didukung oleh hasil penelitian yang dilakukan oleh Sandra., Dewi \& Dewi, (2012) yang meneliti gambaran stress pada pasien gagal ginjal terminal yang menjalani terapi hemodialisa di RSUD Arifin Achmad Pekan Baru didapatkan bahwa sebagian besar pasien mengalami stress tingkat sedang yang diakibatkan oleh persepsi pasien tentang stressor yang mengancam dan waktu menjalani terapi seumur hidupnya. Hal inipun sejalan dengan penelitian Fitriyani, Winarti, dan Sunarsih, (2014) bahwa konsep diri yang negatif menimbulkan kejadian depresi sebanyak 62\%.

Dampak depresi pun tidak hanya dirasakan oleh pasien, keluarga pasien terutama pasangan hidup pasien akan sangat mudah mendapatkan depresi akibat melihat orang yang dicintai menderita, sehingga akan mempengaruhi dukungan dan motivasi yang akan diberikan kepada pasien, terutama pada pasien yang menjalani hemodialisis yang harus menjalani proses cuci darah seumur hidup, sehingga banyak terjadi depresi pada pasien dan keluarganya terutama pasangan hidup pasien (Smeltzer, Bare, Hinkle \& Cheever, 2010). Salah satu faktor pendukung keberhasilan pelayanan keperawatan yaitu dengan melibatkan keluarga pasien (Family Center Care). Dukungan keluarga adalah sikap, tindakan dan penerimaan keluarga terhadap penderita yang sakit. Keluarga juga berfungsi sebagai sistem anggotanya dan anggota keluarga memandang bahwa orang yang 
bersifat mendukung, selalu siap memberi pertolongan dengan bantuan jika diperlukan. Dukungan keluarga pada pasien gagal ginjal kronis yang menjalani hemodialisa terdiri dari dukungan instrumental, dukungan informasional, dukungan emosional dan dukungan harga diri. Dukungan tersebut diberikan sepanjang hidup pasien. Apabila dukungan semacam ini tidak ada, maka keberhasilan penyembuhan / pemulihan (rehabilitasi) sangat berkurang (Friedman, Bowden \& Jones, 2010).

Hasil studi pendahuluan yang dilakukan di RSUD dr Dradjat Prawiranegara pada bulan agustus 2016 tercatat bahwa sebanyak 150 orang penderita penyakit ginjal kronik yang menjalani hemodialisa, dari seluruh penderita rata-rata mereka melakukan hemodialisa 2 kali dalam 1 minggu. Dari hasil wawancara yang peneliti lakukan pada 10 orang penderita gagal ginjal kronik dengan hemodialisa, didapatkan keterangan bahwa tujuh penderita merasa sudah lelah berobat, tidak rutin HD karena tidak ada yang mengantar, tidak semangat HD karena tidak ditemani, merasa bersedih, merasa tidak berguna lagi karena mudah lelah ketika beraktifitas dan sulit untuk tidur, namun dengan kondisi yang seperti itu masih ada beberapa keluarga yang masih menuntut untuk bekerja seperti biasa dan memenuhi tanggung jawabnya.

Berdasarkan uraian latar belakang diatas, tujuan dari penelitian ini adalah hubungan antara dukungan keluarga dengan kejadian depresi pada penderita Penyakit Ginjal Kronik yang menjalani terapi Hemodialisa di Rumah Sakit Umum dr. Dradjat Prawiranegara Serang.

\section{BAHAN DAN METODE PENELITIAN}

Jenis penelitian ini adalah deskriptif analitik melalui pendekatan cross sectional. Cross sectional yaitu suatu penelitian untuk mempelajari dinamika korelasi antara faktor-faktor yang mempengaruhi dan efek dengan cara pendekatan, observasi atau pengumpulan data sekaligus pada suatu saat (Notoatmodjo, S., 2010)

Penelitian ini dilakukan di Ruang Hemodialisa RSUD dr. Dradjat Prawiranegara Serang dengan sampel yang digunakan adalah keluarga pasien dan pasien yang menjalani terapi hemodialisa sebanyak 60 responden. Tehnik 
pengambilan sampel menggunakan purposive sampling yang merupakan jenis Non-probability Sampling. Instrumen yang digunakan untuk mengukur tingkat depresi pasien menggunakan Back Depresion Inventory (BDI) sejumlah 21 pernyataan. Sedangkan instrumen untuk mengukur dukungan keluarga pada keluarga pasien mengadopsi dari teori Friedman. Analisa data terdiri dari analis univariat dan bivariat dengan uji statistik dalam penelitian ini menggunakan $U j i$ Chi Square.

\section{HASIL PENELITIAN}

Hasi Analisa Univariat

Tabel 1. Distribusi frekuensi dukungan keluarga pada penderita penyakit ginjal kronik di RSUD dr.Dradjat Prawiranegara Serang Tahun $2016(n=60)$

\begin{tabular}{ccc}
\hline Dukungan & Jumlah & Presentase \\
\hline Negatif & 32 & $53,3 \%$ \\
\hline Positif & 28 & $46,7 \%$ \\
\hline Jumlah & $\mathbf{6 0}$ & $\mathbf{1 0 0 \%}$ \\
\hline
\end{tabular}

Berdasarkan data diatas dapat dilihat bahwa hampir sebagian besar responden $(53 \%)$ memiliki dukungan keluarga yang negative.

Tabel 2. Distribusi frekuensi kejadian depresi pada penderita penyakit ginjal kronik di RSUD dr.Dradjat Prawiranegara Serang Tahun $2016(\mathrm{n}=60)$

\begin{tabular}{ccc}
\hline Kejadian Depresi & Jumlah & Presentese \\
\hline Minimal & 28 & $46,7 \%$ \\
\hline Ringan & 10 & $16,7 \%$ \\
\hline Sedang & 11 & $18,3 \%$ \\
\hline Berat & 11 & $18,3 \%$ \\
\hline Jumlah & $\mathbf{6 0}$ & $\mathbf{1 0 0} \%$ \\
\hline
\end{tabular}

Berdasarkan data diatas, dapat dilihat bahwa hampir sebagian besar responden (47\%) mengalami depresi yang minimal. 


\section{Hasil Analisa Bivariat}

Tabel 3. Hubungan antara dukungan keluarga dengan kejadian depresi pada penderita penyakit ginjal kronik di RSUD dr.Dradjat Prawiranegara Serang Tahun $2016(n=60)$

\begin{tabular}{|c|c|c|c|c|c|c|}
\hline \multirow{2}{*}{$\begin{array}{c}\text { Dukungan } \\
\text { Keluarga }\end{array}$} & \multicolumn{4}{|c|}{ Tingkat Depresi } & \multirow{2}{*}{ Total } & \multirow{2}{*}{$\begin{array}{c}\mathbf{P} \\
\text { Value }\end{array}$} \\
\hline & Minimal & Ringan & Sedang & Berat & & \\
\hline Negatif & $\begin{array}{c}10 \\
(31,2 \%)\end{array}$ & $\begin{array}{c}4 \\
(12,5 \%)\end{array}$ & $\begin{array}{c}9 \\
(28,1 \%)\end{array}$ & $\begin{array}{c}9 \\
(28,1 \%)\end{array}$ & $\begin{array}{c}32 \\
(100.0 \%)\end{array}$ & \\
\hline Positif & $\begin{array}{c}18 \\
(64,3 \%)\end{array}$ & $\begin{array}{c}6 \\
(21,4 \%)\end{array}$ & $\begin{array}{c}2 \\
(7,1 \%)\end{array}$ & $\begin{array}{c}2 \\
(7,1 \%)\end{array}$ & $\begin{array}{c}28 \\
(100.0 \%)\end{array}$ & 0.010 \\
\hline Total & $\begin{array}{c}28 \\
(46,7 \%)\end{array}$ & $\begin{array}{c}10 \\
(16,7 \%)\end{array}$ & $\begin{array}{c}11 \\
(18,3 \%)\end{array}$ & $\begin{array}{c}11 \\
(18,3 \%)\end{array}$ & $\begin{array}{c}60 \\
(100.0 \%)\end{array}$ & \\
\hline
\end{tabular}

Berdasarkan data diatas hasil analisis hubungan dukungan keluarga dengan kejadian depresi pada penderita penyakit ginjal kronik menunjukkan bahwa dari seluruh responden yang memiliki dukungan keluarga negatif, sebagian kecil responden mengalami depresi sedang (28\%) dan depresi berat (28\%). Sedangkan dari seluruh responden yang memiliki dukungan keluarga positif, sebagian besar mengalami depresi minimal (64\%) dan sangat sedikit responden dengan tingkat kejadian depresi sedang dan berat (7\%).

Berdasarkan uji statistik nilai $\mathrm{p}=0.010$ berarti nilai $\mathrm{p}$ lebih kecil dari nilai alpha 0.05 sehingga dapat disimpulkan bahwa terdapat hubungan yang signifikan antara dukungan keluarga dengan kejadian depresi pada penderita penyakit ginjal kronik.

\section{PEMBAHASAN}

\section{Hasil Analisa Univariat}

a. Gambaran dukungan keluarga pada penderita penyakit ginjal kronik

Hasil penelitian didapatkan data bahwa hampir sebagian besar penderita penyakit ginjal kronik memperoleh dukungan keluarga positif yaitu $28(47 \%)$ responden. Sedangkan yang memperoleh dukungan keluarga negatif sebanyak $32(53 \%)$ responden.

Sejalan dengan penelitian yang dilakukan oleh Luthfa, (2016) didapatkan data bahwa sebagian besar keluarga (68\%) memberikan 
dukungan rendah pada penderita diabetes. Lain halnya dengan penelitian yang dilakukan oleh Yoshima, (2012) ditemukan bahwa dari 50 responden terdapat $7(14 \%)$ responden tidak memperoleh dukungan keluarga dan terdapat $43(86 \%)$ responden memperoleh dukungan keluarga. Sedangkan menurut penelitian Ajeng dan Dessy, (2016) bahwa dukungan keluarga pada pasien gagal ginjal kronik sebagian besar adalah baik.

Dukungan keluarga terhadap penderita penyakit ginjal kronik sangat dibutuhkan dalam proses penyembuhan / pengobatan. Dukungan keluarga memainkan peran penting dalam mengintensifkan perasaan sejahtera, orang yang hidup dalam lingkungan yang supportif kondisinya jauh lebih baik daripada mereka yang tidak memilikinya, karena keluarga adalah orang yang paling dekat hubungannya dengan anggota keluarganya. Keluarga dapat meningkatkan semangat dan motivasi untuk berperilaku sehat yaitu dengan memberikan perawatan dan pengobatan yang layak. dan diperlukan (Friedman, Bowden, \& Jones, 2010).

\section{b. Gambaran kejadian depresi pada penderita penyakit ginjal kronik}

Hasil penelitian didapatkan data bahwa hampir sebagian besar penderita penyakit ginjal kronik yang mengalami depresi minimal yaitu 28 (47\%), ringan yaitu 10 (17\%), sedang 11 (18\%) responden. Sedangkan yang mengalami depresi berat sebanyak 11 (18\%) responden. Hal ini sejalan dengan penelitian yang dilakukan (Tartum dkk, 2016) didapatkan data bahwa dari 34 responden terdapat 7 (21\%) responden tidak mengalami depresi dan terdapat 27 (79\%) responden mengalami depresi.

\section{Hasil Penelitian Bivariat}

\section{Hubungan dukungan keluarga dengan kejadian depresi pada penderita penyakit ginjal kronik}

Hasil analisis tabulasi silang diperoleh bahwa sebagian besar responden yang memperoleh dukungan keluarga positif hanya mengalami depresi minimal (64\%) atau dengan kata lain tidak mengalami depresi dibandingkan dengan responden yang memperoleh dukungan keluarga negatif. Hasil 
penelitian menunjukkan bahwa ada hubungan yang signifikan antara dukungan keluarga dengan kejadian depresi pada responden dengan penyakit ginjal kronik dengan nilai $p$-value $=0,010$. Hasil penelitian sesuai dengan penelitian yang dilakukan oleh Kristyaningsih, (2011) meneliti tentang tingkat depresi pada lansia didapatkan data yang menunjukkan bahwa dukungan keluarga berhubungan secara kuat dengan tingkat depresi lansia dengan nilai $\mathrm{p}$ value 0.000 .

Pelayanan keperawatan yang holistik, diperlukan pendekatan keluarga dalam konteks family centered, yaitu sebuah pendekatan dimana kepedulian tidak hanya ditujukan kepada pasien tetapi juga kepada keluarga pasien karena setiap pasien adalah bagian dari unit keluarga (Duran, Oman, Koziel \& Szymanski, 2007). Konsep Family Centered Care sangat diperlukan untuk proses kesembuhan klien. Peneliti lain yang mengemukakan hubungan antara familiy centered care dengan efek hospitalisasi dilakukan oleh Fiane de Fretes, (2012) teridentifikasi bahwa dari 34 orang tua pasien anak usia 3-6 tahun, jika dikaitkan dengan dengan efek hospitalisasi anak, terdapat 20 orang tua menyatakan efek hospitalisasi pada anak rendah. Sedangkan hasil analisa hubungan dengan riset partisipan orangtua menunjukkan hasil terdapat hubungan antara Family Centered Care dengan efek hospitalisasi pada anak dengan nilai $p$-value sebesar 0,016 .

Hasil penelitian dapat dijelaskan bahwa dukungan keluarga dapat mencegah terjadinya depresi. Dukungan dari keluarga sangat dibutuhkan oleh penderita yang dapat mempengaruhi status psikososial dan mentalnya yang akan ditunjukan dengan perubahan perilaku yang diharapkan dalam upaya meningkatkan status kesehatannya. Peningkatan dukungan tersebut tentunya akan mengurangi terjadinya peningkatan perasaan tidak berguna, tidak dihargai, merasa dikucilkan dan kecewa dari penderita, sekaligus dapat mengurangi terjadinya depresi (Friedman, Bowden \& Jones, 2010).

\section{KESIMPULAN DAN SARAN}

Kesimpulan dari hasil penelitian yang dilakukan di ruang hemodialisa RSUD dr. Dradjat Prawiranegara diketahui bahwa responden yang memiliki 
dukungan keluarga negatif sebagian kecil mengalami depresi sedang dan berat. Sedangkan responden yang memiliki dukungan keluarga positif sebagian besar hanya mengalami depresi minimal atau tidak depresi. Hasil bivariat diperoleh ada hubungan yang signifikan antara dukungan keluarga dengan kejadian depresi pada penderita ginjal kronik yang menjalani hemodialisa.

Dukungan keluarga sangat dibutuhkan dalam proses penyembuhan / pemulihan. Orang yang hidup dalam lingkungan yang supportif dengan memberikan perhatian, kasih sayang, motivasi kondisinya akan jauh lebih baik daripada mereka yang tidak memilikinya. Selain itu, dukungan keluarga dapat meningkatkan kualitas hidup seseorang. 


\section{RUJUKAN}

Ajeng. D., \& Dessy. (2016) Hubungan Dukungan Keluarga Dengan Tingkat Kepatuhan Pasien Hemodialisa terhadap Terapi Gagal Ginjal di RSUD Blambangan Banyuwangi. Jurnal Ilmiah Kesehatan. Vol.1 (1). pp : 21-25.

Arif \& Kumala. (2011). Asuhan Keperawatan Gangguan Sistem Perkemihan. Jakarta : Salemba Medika.

Duran, C.R.,Oman, K.S.,Koziel, V.M., Szymanski, D. (2007). Attitudes Towards and Beliefs about Family Peresence ; A Survey of Healthcare Providers, Patient's Families, and Patients. American Association of Critical Care Nurses Journal. Vol.16 (3). pp : 270-279.

Fiane de Fretes (2012), Hubungan Family Centered Care dengan Efek Hospitalisasi anak di Ruang Dahlia RS Panti Wilasa Citarum, Semarang, Diambil melalui : http://repository.uksw.edu/handle/123456789/2740.

Fitriyani, E.N., Winarti, S.A., \& Sunarsih. (2014). Konsep Diri dengan Kejadian Depresi pada Pasien Gagal Ginjal Kronik yang Menjalani Hemodialisa di RSUD Panembahan Senopati Bantul. Jurnal Ners dan Kebidanan Indonesia Vol.2 (3) hal 122-127.

Friedman, M.M., Bowden, O., \& Jones, M. (2010). Buku ajar keperawatan keluarga: riset, teori, \& praktik. edisi kelima alih bahasa, Achir Yani S. Hamid, et.al. editor bahasa Indonesia, Estu Tiar. Jakarta: Buku Kedokteran EGC.

Kristyaningsih (2011) Hubungan antara dukungan keluarga dengan tingkat depresi pada lansia. Jurnal Keperawatan. Vol. 01 (1). pp : 1-8.

Luthfa. I (2016) Family Support pada Penderita Diabetes Mellitus Tipe 2 di Puskesmas Banget ayu Semarang. Jurnal Keperawatan dan Pemikiran Ilmiah. Vol. 2 (2). pp:1-7

Notoatmodjo, S. (2010). Metodologi penelitian kesehatan. Jakarta : Rineka Cipta.

Perhimpunan Nefrologi Indonesia. (2012). Konsensus Dialisis. Edisi kesatu Jakarta : FIK Universitas Indonesia.

Report of Indonesian Renal Registry. (2014). Program Indonesian Renal Registry diambil melalui http://www.indonesianrenalregistry.org/data/INDONESIAN\%20RENAL\%20R EGISTRY\%202014.pdf.

Riset Kesehatan Dasar. (2013). Profil Kesehatan Provinsi Banten. Melalui : http://dinkes.bantenprov.go.id/archive/profil-kesehatan-provinsi-bant. 
Smeltzer, S. C., Bare, B. G., Hinkle, J, L., \& Cheever, K. H. (2010). Brunner Suddarth`s textbook of medical surgical nursing. $12^{\text {th }}$ edition. Philadelpia: Lippincott. Williams \& Wilkins.

Saeed Z, Ahmad AM, Shakoor A. (2012). Depression in patients on hemodialysis and theire caregiver. Departement of nephrology and psychiatry. Saudi J Kidney Dis Transpl. Vol.23 (5). pp:946-952.

Sandra., Dewi, W.N., \& Dewi, Y.I., (2012). Gambaran stress pada pasien Gagal Ginjal Terminal Yang Menjalani Terapi Hemodialisa di RSUD dr Arifin Achmad Pekan Baru. Jurnal Ners Indonesia, Vol. 2 (2). pp : 99-108.

Tartum, V., Kaunang, T., Elim,C., Ekawardhani, N., (2016). Hubungan Lamanya Hemodialisa dengan tingkat depresi pada pasangan hidup pasien gagal ginjal kronik di RSUP Prof. Dr. R. D. Kandou Manado. Jurnal e-Clinic. Vol 4. (1). pp:41-52.

Yoshima, C.D (2012) Hubungan antara dukungan keluarga dengan kepatuhan pada pasien gagal ginjal kronik dalam menjalani hemodialisis di RSUP Dr.Soeradji Tirtonegoro Klaten. Jurnal Ilmu Keperawatan Respati. Vol.2 (3). pp: 1-22. 